\title{
Correlation of Toxic and Non-toxic Strains of Clostridium botulinum by DNA Composition and Homology
}

\author{
By W. H. LEE AND H. RIEMANN \\ Department of Epidemiology and Preventive Medicine, \\ University of California, Davis, California 956r6, U.S.A.
}

(Accepted for publication 13 October 1969)

\begin{abstract}
SUMMARY
Various toxic and non-toxic Clostridium botulinum strains can be grouped according to DNA binding homology but not according to DNAcomposition. The guanine + cytosine (GC) contents of DNA from six strains were 28 to $30 \%$. DNA binding with radioactive DNA from C. botulinum type E, MINN strain, revealed that the non-proteolytic strains type B, I7, type F, 202 and type E, DETROIT are $100 \%$ homologous to the E, MINN strain. Clostridium botulinum type E, 32, the boticin producing s 5 , and the non-toxic 24 NT, 26 NT and $5 \mathrm{i}$ had 58 to $78 \%$ homology with the MINN strain. Clostridium botulinum type A, 62 and 78, type B, 32, type C, 573, and non-toxic OS/E I, OS/E 7 and OS/MINN strains had only 6 to $14 \%$ homology with type E, MINN. Competition experiments with unlabelled DNA confirmed these results. The studies indicate that strains which are closely related serologically and biochemically are also closely related genetically, and vice versa. The data do not support the idea of a common origin of the non-toxic os strains and C. botulinum type $\mathrm{E}$. The toxic type E strains and the toxic type $\mathrm{A}, \mathrm{B}$ and $\mathrm{C}$ strains of $C$. botulinum are genetically heterogenous.
\end{abstract}

\section{INTRODUCTION}

The species Clostridium botulinum includes heterogenous strains that produce toxins types A to F. Based on physiological and serological characteristics, the specie: can be divided into the proteolytic A group, the non-proteolytic $\mathrm{E}$ group, and the $\mathrm{C}$ group (Smith \& Holdeman, 1968, see Table 2). In recent years, non-proteolytic C. botulinum types B and F with characteristics of the type E group have been reported (Eklund \& Poysky, 1967). Many non-toxic strains, such as 24 NT and 26 NT isolated from the North Sea (Cann et al. 1965) and the boticin producing S 5 and 28-2 isolated from the Great Lakes (Kautter, Harmon, Lynt \& Lilly, 1966), were reported to have identical characteristics with type E. Non-toxic os (opaque sporulating) strains were closely associated with type E cultures (Dolman, 1957). The os strains have different fermentation, serological reactions and spore structure than the type E strains (Hobbs, Roberts \& Walker, 1965; Hodgkiss, Ordal \& Cann, I966; Walker \& Batty, 1967).

Non-toxic Clostridium botulinum strains are difficult to classify because this species is solely defined by toxin formation. Thus all non-toxic $C$. botulinum strains are named by numbers and numerals like 24 NT or $5 \mathrm{i}$. The characteristics of the strains tested are summarized in Table $\mathrm{I}$.

The purpose of this study is to examine the genetic relationship of various toxic and non-toxic Clostridium botulinum strains with the type E strains. The difference in DNA 
base composition can be used as a measure of genetic relatedness (Marmur \& Doty, I962; Schildkraut, Marmur \& Doty, I962; Hill, I966). McCarthy \& Bolton (1963) measured the genetic relatedness of organisms by the binding of complementary DNA base sequences in vitro. The DNA composition and the degree of common DNA base sequence of 22 toxic and non-toxic $C$. botulinum strains were measured in this study.

Table I. General characteristics of Clostridium botulinum groups $A, C$ and $E$ (Smith \& Holdeman, I968; Roberts \& Hobbs, I968)

\begin{tabular}{|c|c|c|c|c|c|}
\hline Group & $\begin{array}{c}\text { Serological } \\
\text { reaction of } \\
\text { vegetative cells }\end{array}$ & Proteolysis & $\begin{array}{l}\text { Gas } \\
\text { formation in } \\
\text { carbohydrate } \\
\text { fermentation }\end{array}$ & $\begin{array}{l}\text { Minimum } \\
\text { growth } \\
\text { temperature }\end{array}$ & $\begin{array}{c}\text { Resistance } \\
\text { of spores } \\
\text { to heat }\end{array}$ \\
\hline $\mathbf{A}$ & $A, B$ and $F$ & Strong & Weak & $\begin{array}{c}>10^{\circ} \\
\left(\text { type } \mathrm{F} \text { to } 4^{\circ}\right)\end{array}$ & $>100^{\circ} 10 \mathrm{~min}$. \\
\hline C & $\mathrm{C}$ and $\mathrm{D}$ & Weak & Weak & $>10^{\circ}$ & $\sim 90^{\circ} 10 \mathrm{~min}$. \\
\hline E & $\begin{array}{l}\mathrm{E} \text { and non-proteolytic } \\
\mathbf{B} \text { and } \mathbf{F}\end{array}$ & Weak & Strong & $3^{\circ}$ & $\sim 60^{\circ} 30 \mathrm{~min}$. \\
\hline$(O s)^{*}$ & os & Weak & Weak & $5^{\circ}$ & $\sim 90^{\circ}$ 10 min. \\
\hline
\end{tabular}

\section{METHODS}

Cultures. Toxic cultures Clostridium botulinum A, 62, A, 78, B, 32, C, 573, E, MINNESOTA (MINN) and E, DETROIT were obtained from K. Ito (National Canners Assoc., Berkeley, Calif.) and C. botulinum E (Wellcome \# 3324/6I) was obtained from A. Johannsen (Lund, Sweden). Non-proteolytic strains C. botulinum B, I7 and F, 202 were obtained from M. W. Eklund (Eklund \& Poysky, 1967). C. botulinum F, LANGELAND was obtained from V. Møller (State Serum Institute, Copenhagen, Denmark). Clostridium sporogenes 2I3 was obtained from L. S. McClung (Indiana U., Bloomington, Ind.). Non-toxic strains 24 NT, 26 NT were isolated by G. Hobbs (Torry Research Station, Aberdeen, Scotland). The boticin producing non-toxic strains s 5 and $28-2$ were isolated by Kautter et al. (I966). Non-toxic strains os/E I and os/E 7 were obtained from C.E. Dolman (I957). Non-toxic os/MINN and 5 i were picked from the C.botulinum type $\mathrm{E}, \mathrm{MINN}$ culture in our laboratory.

Medium and growth conditions. Unlabelled DNA from all strains was isolated from organisms grown in I to 21 . of medium: proteose peptone $20 \mathrm{~g}$., yeast extract $15 \mathrm{~g}$. (Difco), soluble starch I g., mercaptoethanol $0.5 \mathrm{ml} . \mathrm{K}_{2} \mathrm{HPO}_{4} \mathrm{I} \cdot 85 \mathrm{~g} . / 1$., $\mathrm{pH}$ adjusted to $7 \cdot 2$ with $\mathrm{NaOH}$. Mercaptoethanol and $\mathrm{FeSO}_{4}$ generate a $\mathrm{Eh}$ of $-275 \mathrm{mv}$ in solution (Wood, I966). Glucose Io g./1. was sterilized separately. Organisms were grown at $37^{\circ}$ for 7 to $24 \mathrm{hr}$ under 25 in. vacuum in a Duravac plastic desiccator (Ace Glass Inc., Vineland, N.J.) which had been flushed with a gas mixture $\left(\mathrm{N}_{2} 88 \%, \mathrm{CO}_{2} 10 \%\right.$, $\mathrm{H}_{2} 2 \%$ ). Clostridium botulinum $\mathrm{C}, 573$ grew only in the following medium: liver infusion $35 \mathrm{~g}$., meat extract (Difco) I5 g., cysteine-HCl I g., and glucose (sterilized separately) 6.7 g./1. Radioactive DNA of Clostridium botulinum E, MINN was prepared from organisms grown in I 1. of Edamin medium: Edamin S (Sheffield Chemicals, Norwich, N.J.) 40 g., soluble starch I g., mercaptoethanol $0.5 \mathrm{ml}$., Triton $\times$ I 55 (Rohm \& Hass, Philadelphia, Pa.) $0.4 \mathrm{~g}$./1., pH adjusted to $7 \cdot 4$ with $\mathrm{KOH}$. Glucose Io g./1. was sterilized separately. The growth conditions were as described above. 
After $4 \mathrm{hr}$ of growth, $385 \mu \mathrm{C}$ of thymidine- ${ }^{3} \mathrm{H}$, which was placed in a floating small plastic cup, was mixed into the culture medium with a magnetic stirrer. The organisms were harvested $2 \mathrm{hr}$ later.

DNA isolation. Lysis of Clostridium botulinum can be difficult to accomplish by standard methods but the following procedure was effective in recovering some DNA from all the strains tested. Acetone dried organisms were sonicated for about $6 \mathrm{~min}$. in ethanol in the cold, dried and suspended in 10 to $20 \mathrm{ml}$. saline + EDTA buffer $(\mathrm{NaCl}$ $0.15 \mathrm{M}, \mathrm{Na}_{2} \mathrm{EDTA}$ O.I M, pH 8.0). The suspension was treated with about I mg lysozyme $/ \mathrm{ml}$. at $40^{\circ}$ for $\frac{1}{2} \mathrm{hr}$. Then about $\mathrm{I} \mathrm{mg}$. pronase (Calbiochem, Los Angeles, Cal.) $/ \mathrm{ml}$. and I \% sodium lauryl sulphate(SLS) were added and incubated for I to $5 \mathrm{hr}$. The time of lysis of the various strains differed and lysis could occur at any stage of the treatment. The treatment was terminated when the solution became highly viscous. The released DNA was purified by Marmur's (196I) method for Tm and buoyant density analysis and by Miura's (I967) method for the binding and competition studies. Clostridium perfringens DNA was purchased from Worthington Biochem. Corp., Freehold, N.J.

Analytical methods. DNA was determined chemically by Burton's (1968) method and spectrophotometrically by increase in optical density upon heating (Hotchkiss, 1957). Molecular weight was measured by the method of Zimm \& Crothers (1962) in a Couette viscometer. The GC content of DNA was determined in duplicate samples by the Tm method (Marmur \& Doty, 1962) and checked by the buoyant density method with Micrococcus lysodeikticus DNA (Miles Lab., Erkhart, Ind.) as reference (Schildkraut et al. 1962). DNA binding was assayed by the method of Denhardt (1966). DNA $(30 \mu \mathrm{g}$.) was applied to each $25 \mathrm{~mm}$. Millipore HA filter and annealed with $2 \mu$ g. DNA- ${ }^{3} \mathrm{H}$ (Io,000 c.p.m.) at $66^{\circ}$ for $\mathrm{I} 2 \mathrm{hr}$. For competition experiments, $875 \mu \mathrm{g}$. of Clostridium botulinum type E, MINN DNA was applied to a $90 \mathrm{~mm}$. Millipore HA filter. Small I I mm. circles were punched from the $90 \mathrm{~mm}$. filter. Two I I $\mathrm{mm}$. filters were annealed with $250 \mu \mathrm{g}$. of various unlabelled DNA and I $\mu$ g. DNA- ${ }^{3} \mathrm{H}$ (5,000 c.p.m.) in 0.3 or $0.5 \mathrm{ml}$. double strength citrate (SSC) at $66^{\circ}$ for $\mathrm{I} 2 \mathrm{hr}$. Thermal denaturation of duplex DNA formed on filters was measured by the radioactivity released from two I I $\mathrm{mm}$. filters during heating in I $\mathrm{ml}$. SSC. The heated solution and I $\mathrm{ml}$. rinsing SSC were combined and the radioactivity determined in $15 \mathrm{ml}$. scintillation solution: Toluene 2 1., Triton $\times$ Ioo (Rohm \& Haas, Philadelphia, Pa.) I 1., Spectroflour (Nuclear-Chicago, Des Plaines, Ill.) roo ml. (Peterson and Greene, 1965). The radioactivity of dry filters were also counted in $15 \mathrm{ml}$. of the same scintillation solution.

\section{RESULTS}

DNA composition. The GC contents of 6 Clostridium botulinum strains are presented in Table 2. The thermal denaturation curve of $C$. botulinum $\mathrm{E}$, MINN DNA is shown in Fig. I. No satellite band was observed in the buoyant density photographs of DNA from $C$. botulinum E, MINN which produces type E toxin, or DNA from S 5, which produces boticin.

DNA molecular weight, binding and competition. The molecular weight of isolated DNA varied from strain to strain. The mol. wt of DNA from Clostridium botulinum type E, $3324 / 6 \mathrm{I}$, which was easy to isolate, was $\mathrm{I} \cdot \mathrm{I} \times 1 \mathrm{I}^{7}$. Clostridium botulinum type E, MINN DNA degraded during lysis. Heating the cell suspension to $70^{\circ}$ for $15 \mathrm{~min}$., 
addition of 0. I M-EDTA and I \% SLS did not prevent DNA breakdown. The mol. wt of the unlabelled type E, MINN DNA used in these experiments was $4.2 \times 10^{6}$, and in one batch it was only $2.4 \times 10^{6}$. Strains $5 \mathrm{i}$ and $C$. botulinum $\mathrm{F}, 202$ DNA degraded very rapidly. Lysis of these two strains was accomplished by adding $\mathrm{I} \%$ SLS to unwashed cells in ice for $5 \mathrm{~min}$. and then phenol was added to prevent DNA breakdown. The

Table 2. The GC content of toxic and non-toxic Clostridium botulinum strains

\begin{tabular}{clcc} 
Group & \multicolumn{1}{c}{ Strain } & Tm method & $\begin{array}{c}\text { Buoyant } \\
\text { density } \\
\text { method }\end{array}$ \\
A & C. botulinum A, 62 & $28 \cdot 5 \%$ & - \\
A & C. botulinum B, 32 & 29.3 & - \\
E & C. botulinum E, MINN & $27 \cdot 9^{*}$ & $28 \cdot 8 \%$ \\
E & S5 (boticin) & 28 & $29 \cdot 6$ \\
E & 24 NT & 29 & - \\
E? & OS/E $7 \quad 30$ & - \\
& & &
\end{tabular}

Table 3. Percentage binding and competition of DNA from various strains relative to the Clostridium botulinum E MINN strain

\begin{tabular}{|c|c|c|c|c|}
\hline Group & Toxic strains & Source & Binding* & $\begin{array}{c}\text { Compe- } \\
\text { tition } \dagger\end{array}$ \\
\hline $\mathrm{E}$ & C. botulinum $\mathrm{E}, \mathrm{MINN}$ & Fish, Great Lakes & $100 \%$ & $100 \%$ \\
\hline $\bar{E}$ & C. botulinum E, DETROIT & Fish, Great Lakes & 100 & 99 \\
\hline E & C. botulinum $\mathrm{E}, 3324 / 6 \mathrm{I}$ & Fish, Baltic Sea & 68 & 100 \\
\hline A & C. botulinum A, 62 & Cow, Nevada & II & 0 \\
\hline A & C. botulinum A, 78 & Spinach, U.S. & 14 & 20 \\
\hline A & C. botulinum $\mathrm{B}, 32$ & Horse & II & 3 \\
\hline $\mathrm{E}$ & C. botulinum в, 17 & Pacific mud, U.S. & 100 & 100 \\
\hline $\mathrm{C}$ & C. botulinum c, 573 & Horse, France & II & - \\
\hline $\mathbf{E}$ & C. botulinum $\mathrm{F}, 202$ & Pacific mud U.S. & 100 & 100 \\
\hline \multirow[t]{2}{*}{ A } & C. botulinum $\mathrm{F}$, LANGELAND & Liver, Denmark & I9 & 52 \\
\hline & Non-toxic strains & & & \\
\hline $\mathbf{E}$ & s5, Boticin & Fish, Lake Erie & 78 & 80 \\
\hline $\mathbf{E}$ & 28-2, Boticin & Mud, Lake Huron & 43 & 89 \\
\hline $\mathbf{E}$ & $24 \mathrm{NT}$ & Mud, North Sea & 69 & 95 \\
\hline$\overline{\mathrm{E}}$ & $26 \mathrm{NT}$ & Mud, North Sea & 58 & 65 \\
\hline $\mathrm{E}$ ? & $5 \mathrm{i}$ & Toxic E MINN & 73 & - \\
\hline $\mathrm{E}$ ? & OS/E I & Toxic E culture & 8 & 0 \\
\hline E? & OS/E 7 & Toxic E culture & 6 & 0 \\
\hline $\mathrm{E}$ ? & os/MINN & Toxic E culture & 9 & 0 \\
\hline- & C. perfringens & - & 23 & 0 \\
\hline A? & C. sporogenes 213 & U.S. & 12 & I3 \\
\hline $\mathrm{A}$ ? & P. A. 3679 & U.S. & II & - \\
\hline- & Micrococcus lysodeikticus & - & 4 & - \\
\hline
\end{tabular}

binding of DNA from various strains relative to type E, MINN DNA is presented in Table 3. From I to $250 \mu \mathrm{g}$. of type E, MINN and S5 DNA was applied to each filter and maximum binding was observed at about $20 \mu \mathrm{g}$. level. The DNA duplexes formed on filters were stable and had a similar thermal denaturation curve to the native DNA, but the Tm was lowered by $4^{\circ}$ (Fig. I). The average count and its standard deviation 
for 16 replicates of type E, MINN DNA was $234 \mathrm{I} \pm 48 \mathrm{I}$ counts $/ \mathrm{min}$. The results of the competition experiments are presented in Table 3 . In these experiments the binding was 1000 counts $/ \mathrm{min}$. without the competing DNA and the binding was reduced to I00 counts/min. with $250 \mu \mathrm{g}$. of its own competing DNA. The competition experiment was limited to I or 2 replicates because of the limited supply of DNA.

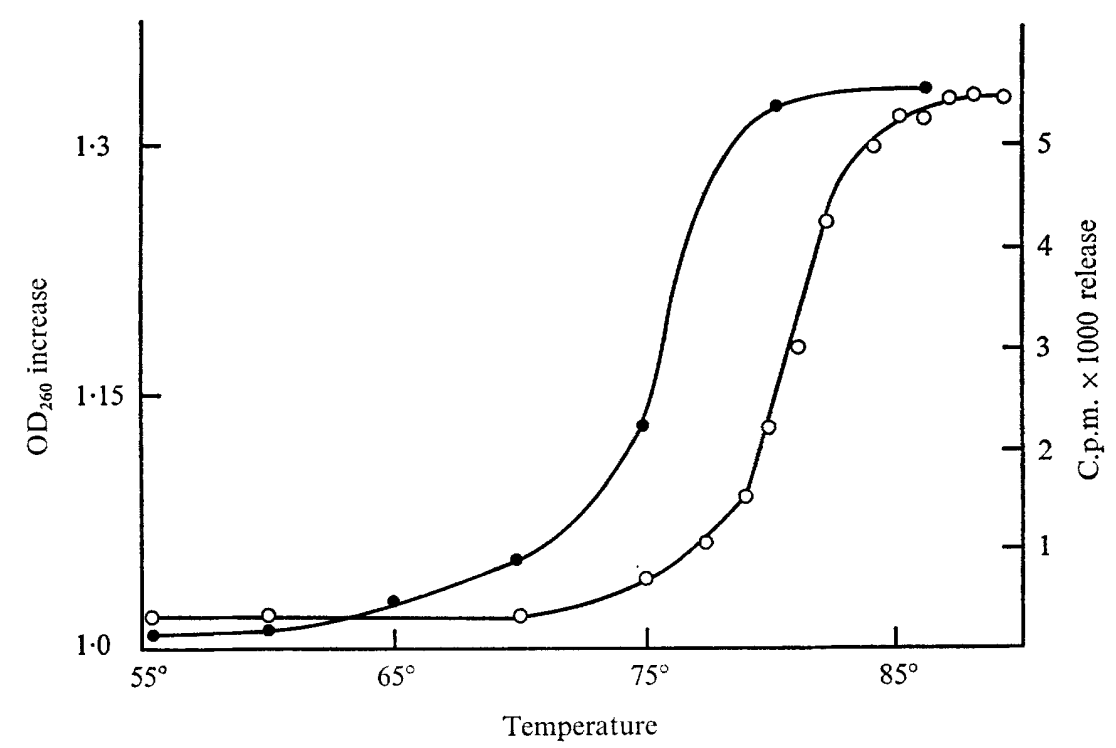

Fig. I. Thermal denaturation of Clostridium botulinum E, MINN native DNA $(\bigcirc)$ and radioactive duplex annealed on filters at $66^{\circ}(\bullet)$.

\section{DISCUSSION}

The DNA composition of the examined Clostridium botulinum strains (Table 2) was similar to that of $C$. perfringens and $C$. sporogenes (Hill, I966). Since the six strains tested have similar GC composition, the analysis has no taxonomic value with respect to $C$. botulinum strains.

Results of the DNA binding and competition tests were more revealing. They agreed with the characteristics of three groups of Clostridium botulinum. The toxic C. botulinum, E, DETroIT, E, 3324/6I, B, I7 and F, 202 (Eklund, Poysky \& Wieler, 1967) strains were reported to have the characteristics of the E group. These strains had 70 to $1000 \%$ DNA binding with the E, MINN strain and hence are closely related (Table 3). The non-toxic s 5, 28-2, 24 NT and 26 NT were also reported to be identical to the toxic type E group (Kautter et al. 1966; Cann et al. 1965). These non-toxic strains have 40 to $80 \%$ DNA binding with E, MINN DNA and hence are also closely related to the toxic E group. Both $5 \mathrm{i}$ and os/MINN were isolated from $C$. botulinum $\mathrm{E}$, MINN culture. If E, MINN were the parent of $5 \mathrm{i}$ and OS/MINN strains, all three strains should have nearly all common DNA base sequences and nearly $100 \%$ DNA binding. The binding of 5 i DNA to E, MINN was only $73 \%$ (Table 2 ). The DNA of 5 i was always degraded during isolation and this might reduce its binding from the expected $100 \%$ to a value of $73 \%$. The binding of Os/MINN to E, MINN DNA was only $8 \%$ (Table 3 ). This means that OS/MINN, like the unrelated control Micrococcus lysodeikticus (4\%), have 
very little common DNA base sequence with the E, MINN (Table 2). No mutations are known to change DNA base sequence so completely. Based on present knowledge, it seems improbable that os/MINN could have originated by mutation from the E, MINN. The same reasoning applies to the other os strains and their genetic relatedness to Clostridium botulinum type E. The other os strains had only $8 \%$ homology (Table 3 ) with the E, MINN DNA and thus are not related to the E group. Although these os strains have close association with the C. botulinum type E (Dolman, 1957), many differences in their fermentation serology and structure have been noted (Hobbs et al. 1965; Walker \& Batty, 1967; Hodgkiss et al. 1966).

Many of the characters of toxic Clostridium botulinum groups $\mathrm{A}$ and $\mathrm{C}$ are different from the E group. The binding of $C$. botulinum types A, 62, A, 78, B, 32 and $\mathrm{C}, 573$ DNA to E, MINN DNA was I I to I $4 \%$ and therefore we concluded that they are not closely related to the E group (Table 3). Clostridium botulinum type F, LANGELAND DNA appeared to have little more common DNA base sequence with E, MINN than the toxic type A, B and C strains tested. Generally the DNA homology among the groups of C. botulinum is low compared to the genera of Enterobacteriaceae. The DNA homology of the genera Escherichia, Aerobacter, Salmonella and Shigella were found to be 50 to $70 \%$ (McCarthy \& Bolton, I963). The species C. botulinum seems to include genetically heterogenous strains which are classified together only because they form toxins with similar pharmacological action.

The non-toxic Clostridium sporogenes and P.A. 3679 have some characteristics of the toxic Clostridium botulinum group A (Kindler, Mager \& Grossowicz, 1956; Smith \& Holdeman, I968); C. sporogenes 213 and P.A. 3679 had only 10\% DNA homology with E, MINN, and so are not related to the E group. We plan to study the DNA homology of $C$. botulinum type A, B and F strains and their related non-toxic strains like C. sporogenes and P.A. 3679. Eventually a systematic study of Clostridium DNA homology could lead to a better classification of this genus.

We wish to thank S. A. Douglas for running the Spinco E ultracentrifuge. This study was supported by U.S. Public Health Grant UI 00262-03 and was sponsored by the Food Protection and Toxicology Centre, University of California, Davis.

\section{REFERENCES}

AJMal, M. \& HobBs, B. C. (1967). Incidence and significance of colonial variation in Cl. botulinum type E. In Botulism 1966. Ed. by M. Ingram and T. A. Roberts, p. 459. London: Chapman and Hall.

BURTON, K. (1968). Determination of DNA concentration with diphenylamine. Methods in Enzymology $12 \mathrm{~B}, \mathrm{I} 63$.

Cann, D. C., Wilson, B. B., Hobbs, G., Shewan, J. M. \& Johannsen, A. (1965). The incidence of Clostridium botulinum type $\mathrm{E}$ in fish and bottom deposits in the North Sea and of the coast of Scandinavia. Journal of Applied Bacteriology 28, 426.

DenhaRDT, D. T. (1966). A membrane filter technique for the detection of complementary DNA. Biochemical and Biophysical Research Communications 23, 64I.

Dolman, C. E. (1957). Recent observations on type E botulism. Canadian Journal of Public Health $48,187$.

ExLund, M. W. \& Poysky, F. T. (1967). Incidence of C. botulinum type $\mathrm{E}$ from the Pacific coast of the United States. In Botulism 1966. Ed. by M. Ingram and T. A. Roberts, p. 49. London: Chapman and Hall.

EkLund, M. W., Poysky, F. T. \& Wieler, D. I. (1967). Characteristics of Clostridium botulinum type F isolated from the Pacific coast of the United States. Applied Microbiology I5, I3I6. 
HiLl, L. R. (1966). An index to deoxyribonucleic acid base compositions of bacterial species. Journal of General Microbiology 44, 4I9.

HobBs, G., RoBerTs, T. A. \& WALKER, P. D. (1965). Some observations on os variants of Clostridium botulinum type E. Journal of Applied Bacteriology 28, 147.

Hodgkiss, W., ORDAL, Z. J. \& CANN, D. C. (1966). The comparative morphology of the spores of Clostridium botulinum type $\mathrm{E}$ and the spores of the 'os' mutant. Canadian Journal of Microbi ology 12, 1283.

HotchKIss, R. D. (1957). Methods for characterization of nucleic acid. Methods in Enzymology 3, 708.

Kautter, D. A., Harmon, S. M., Lynt, R. K., Jun. \& Lilly, T., Jun. (I966). Antagonistic effect on Clostridium botulinum type E by organisms resembling it. Applied Microbiology I4, 616.

KIndLeR, S. H., MAGER, J. \& Grossowicz, N. (1956). Nutritional studies with Clostridium botulinum group. Journal of General Microbiology 15, 386.

MCCARTHY, B. J. \& Bolton, E. T. (1963). An approach to the measurement of genetic relatedness among organisms. Proceedings of the National Academy of Sciences of the United States of America 50, I56.

MARMUR, J. (I96I). A procedure for the isolation of deoxyribonucleic acid from micro-organisms. Journal of Molecular Biology 3, 208.

MARMUR, J. \& DoTY, P. (1962). Determination of the base composition of deoxyribonucleic acid from its thermal denaturation temperature. Journal of Molecular Biology 5, 109.

Miura, K.-I. (I967). Preparation of bacterial DNA by phenol-pH9-RNAses method. Methods in Enzymology 12A, 543.

Peterson, M. S. \& Greene, R. C. (1965). Measurement of low energy beta-emitters in aqueous solution by liquid scintillation counting in emulsion. Analytical Chemistry 37, 854 .

RoBerTs, T. A. \& HobBs, G. (1968). Low temperature growth characteristics of Clostridia. Journal of Applied Bacteriology 31, 75.

Schildkraut, C. L., Marmur, J. \& Doty, P. (1962). Determination of the base composition of deoxyribonucleic acid from its buoyant density in CsCl. Journal of Molecular Biology 4, 430.

Smith, L. D. S. \& Holdeman, L. V. (1968). The Anaerobic Bacteria. Springfield, Ill.: Charles C. Thomas.

WALKER, P. D. \& BATTY, I. (1967). The serology of C. botulinum with reference to fluorescent staining. In Botulism 1966. Ed. by M. Ingram \& T. A. Roberts, p. 482. London: Chapman and Hall.

WooD, N. P. (1966). Control of oxidation-reduction potential during purification. Methods in Enzymology 9, 3.

ZIMM, B. H. \& CROTHERS, D. M.(1962). Simplified rotating cylinder viscometer for DNA. Proceedings of the National Academy of Sciences of the United States of America 48, 905. 